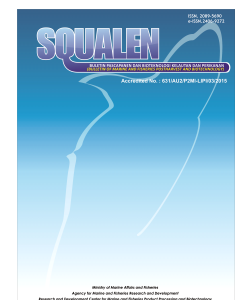

www.bbp4b.litbang.kkp.go.id/squalen-bulletin

Squalen Bulletin of Marine and Fisheries Postharvest and Biotechnology

ISSN: 2089-5690

e-ISSN: 2406-9272

\title{
Design and Performance of Scaled-Up Microwave Dryer for Seaweed Drying
}

\author{
Arif Rahman Hakim*, Wahyu Tri Handoyo, and Adrianto Widi Prasetya \\ Research Institute for Fisheries Postharvest Mechanization, Ministry of Marine Affairs and Fisheries Republic of Indonesia, \\ JI. Imogiri Barat KM 11.5, Yogyakarta, Indonesia 55781 \\ Article history: \\ Received: 3 April 2020; Revised: 28 July 2020; Accepted: 3 November 2020
}

\begin{abstract}
Direct sunlight is commonly used to dry fresh seaweed by artisanal farmers in Indonesia due to its low cost and ease of handling. Nevertheless, this method poses some drawbacks such as lengthy duration, weather dependency and quality degradation. The application of microwave technology in food processing has progressed dramatically, including in the drying process. The microwave drying method is more efficient and can shorten the processing time. This study aimed to describe a large-scale microwave dryer (MD) design and performance to assist the fresh seaweed drying process. The design concept applies microwave energy with a volumetric heating feature to accelerate the seaweed drying process without damaging its functional groups. The MD dimensions were 2410 (I) x 270 (w) $\times 210$ (h) $\mathrm{mm}$ with a dryer capacity of up to six kilograms, an enlarged cavity and multiple magnetrons. The main components of the MD were cavity, air circulation system, drying system and control system. According to the performance testing, the MD's optimum performance was at a power level setting of P7 and six kilograms load. At this setting, we obtained a dried seaweed with a moisture ratio of $0.68 \pm 0.05$, drying rate of $30.29 \pm 1.32 \mathrm{~g} / \mathrm{min}$, specific energy consumption of $3.96 \pm 0.08 \mathrm{MJ} / \mathrm{kg} \mathrm{H} \mathrm{H}_{2} \mathrm{O}$ and energy efficiency of $58.45 \pm 2.65 \%$. The total power of the P7 setting operation required $2.00 \mathrm{~kW}$. Fourier-Transform Infrared (FTIR) spectra showed that the functional groups of the dried seaweed were unaltered.
\end{abstract}

Keywords: microwave dryer, seaweed, design

\section{Introduction}

The red alga Kappaphycus alvarezii (formerly known as Eucheuma cottonii) is the source of kappacarrageenan. Carrageenan has been widely utilized in many industrial applications such as food industry, pharmaceuticals, cosmetics and others (Adharini, Suyono, Suadi, Jayanti \& Setyawan, 2019). Recently, the seaweed processing industry has been growing rapidly due to the increasing demand for carrageenan (Jumaidin, Sapuan, Jawaid, Ishak, \& Sahari, 2017). The persisting challenge in the seaweed post-harvest industry is the handling of fresh seaweed that requires a dehydration process.

Since seaweed contains more than $80 \%$ of water, the most critical process in the post-harvest step is removing the water effectively. Seaweed with low moisture content prolongs quality and facilitates further treatments such as storage, transportation and processing (Djaeni, Mohamad, \& Sari, 2015). Artisanal farmers currently use direct sunlight to dry the harvested seaweed because it is easy and inexpensive (Hakim, Handoyo \& Prasetya, 2019). However, the direct sunlight drying method is weather-dependent, time-consuming and insanitary (Djaeni, Sasongko, \& Van Boxtel, 2013). Many studies have been conducted to deal with these complications. Fudholi, Sopian, Othman and Ruslan (2014) studied the energy and exergy of the solar drying system of red seaweed resulting in a final product with $10 \%$ moisture content. Naim, Burhanuddin, Lapondu and Roslan (2018) managed to achieve a final moisture content of $10.5 \%$ using a cabinet dryer powered by liquid petroleum gas (LPG). Surata, Nindhia and Atmika (2012) used a cabinet dryer to produce dried E. spinosum with 31$35 \%$ moisture content. These studies used either a conductively or conventionally heat transfer mechanism for the drying process. However, the drying

${ }^{*}$ Corresponding author.

E-mail: arifrahmanh11@gmail.com 
process is still inefficient in terms of duration and energy consumption. For example, the solar drying process required 15 hours to reduce moisture content in seaweed by $80 \%$ and specific energy consumption (SEC) of $9.43 \mathrm{MJ} / \mathrm{kg} \mathrm{H}_{2} \mathrm{O}$, resulting in $27 \%$ efficiency of the system (Fudholi et al., 2014). The LPG-powered cabinet dryer required $28.25 \mathrm{~kJ}$ and 100 mins to dry two kilograms of seaweed (Naim et al., 2018). The energy and time inefficiencies in these studies agreed with other studies (Demiray, Seker and Tulek, 2017; Feng \& Tang, 1998; Wang \& Xi, 2005). Drying food products by convection and conduction generally lengthens the time, particularly during the falling rate period, because the heat transfer to the inner sections of foods is limited.

The microwave emerges as an alternative technology for the drying process and has gained popularity in the food industry. Microwave technology offers a faster and more efficient process $(49.33 \pm 8.08 \%)$ than the conventional method $(3.55 \pm 0.1 \%)$ due to the high mass transfer coefficient (Askari, Emam-Djomeh \& Mousavi, 2013). Drying peppermint leaves in microwave energy resulted in more energy efficiency and shorter processing time (14 $\pm 2.5 \mathrm{mins})$ than the hot air drying method $(270 \pm 8.01$ mins) (Torki-Harchegani, Ghanbarian, GhasemiPirbalouti \& Sadeghi, 2016).

Companies have created commercial microwave dryers (MD), but they are usually designed for a small scale. Meanwhile, a scaled-up MD has been assembled only for paddy with an SEC of $49.78 \mathrm{MJ} /$ $\mathrm{kg}$ and energy efficiency of $36.29 \%$ (Jafari, Kalantari \& Azadbakht, 2017). This scaled-up dryer had an optimal load sample only at $18 \mathrm{~mm}$ thickness; hence it was not suitable to be applied for a bulky material such as seaweed. Additionally, fresh seaweed contains $80 \%$ of moisture content compared to paddy with an initial moisture content of $24.46 \%$. Consequently, a scaled-up MD for seaweed needs a different consideration of the design, i.e., the number of magnetrons and cavity volume.

In our preliminary study, a simulation of lab scaleMD for seaweed dehydration has been generated (Hakim, Handoyo \& Prasetyo, 2020a) with a capacity optimum of $730 \mathrm{~g}$ of fresh seaweed and $11.53 \mathrm{~g} / \mathrm{min}$ of drying rate. Therefore, this study aimed to design and test a large-scale MD's performance with a capacity of $2-6 \mathrm{~kg}$ of fresh seaweed.

\section{Material and Methods}

\subsection{Material}

Equipment used in this study were magnetron type RV-MZA382WRZZ, waveguide model R-28STM
WR340, exhaust fan for top side (WINNER Axial FAN Model RQA12038HSL) 200v/240v, $50 / 60 \mathrm{~Hz}$, $0.14 \mathrm{~A} 21 \mathrm{~W} 2 \mathrm{P}$ with a $120 \mathrm{~mm}$-diameter, fan for rear side (San Ace Model 109S025), Oriental Motor model SCM560GVH-EC, $2 \mathrm{~mm}$-thick aluminium sheet, $2 \mathrm{~mm}$ thick stainless steel sheet type 304, a copper sheet of 0.4-mm thick, digital scales (ACIS Multi-Function AW Series AW-15X), digital clamp meter Tang Ampere Sanwa DCM400AD, Oven Memmert UN110, and Fourier Transform Infrared (FTIR) spectroscopy (Thermo Scientific Nicolet iS10).

The dimensions of the cavity, magnetrons, and electromagnetic behavior were calculated using numerical modeling, facilitated by Comsol Multiphysics 5.4 software. For the detailed 3D drawing of MD, SolidWorks 2012 software was used. These software programs were operated on a desktop PC equipped with Intel Core i5-2320, $3.00 \mathrm{GHz}$ processor, 16 GB RAM and 64-bit Windows 7 Ultimate.

The fresh seaweed material $K$. alvarezii was harvested from Bluto beach in Sumenep, Indonesia in July 2019. During transportation to the Research Institute for Fisheries Postharvest Mechanization laboratory in Bantul regency, seaweed was packed in an insulated container. The temperature maintained at $5-10^{\circ} \mathrm{C}$ using ice flake. The initial moisture content of fresh seaweed was determined using a standard oven method, and the average value was $86.52 \%$. The fresh seaweed characteristics were as follows: bulk density of $0.24 \mathrm{~g} / \mathrm{cm}^{3}$, specific heat capacity of 500.08 $\mathrm{cal} / \mathrm{g}$ and moisture equilibrium of $28.78 \%$.

\subsection{Design and Construction}

The design of MD was based on a microwave oven with three main components, i.e., power sources, cavity resonator and transmission line. MD's capacity was designed for $6-7 \mathrm{~kg}$ with a surface area of $6.5 \times 10^{5}$ $\mathrm{mm}^{2}$ and dimensions of $2410 \mathrm{~mm} \times 270 \mathrm{~mm}(\mathrm{I} \times \mathrm{w})$. The acceleration of the drying rate was targeted at above $13.15 \mathrm{~g} / \mathrm{min}$, where the total surface area of the cavity was $6.5 \times 10^{5} \mathrm{~mm}^{2}$, and the width was $270 \mathrm{~mm}$. The length area was calculated using Equation 1 as follows:

$$
\text { Length area }(\mathrm{cm})=\frac{\text { Total surface area }\left(\mathrm{cm}^{2}\right)}{\text { Width area }(\mathrm{cm})}
$$

Magnetrons. The magnetrons' maximum frequency was $2.5 \mathrm{GHz}$ to meet industrial and household purposes (Atuonwu \& Tassou, 2018). GAE (2009) and Monteiro, Carciofi, Marsaioli and Laurindo (2015) described a simple measure of the magnetrons' maximum power density in a loaded cavity. The number of magnetrons was determined using Equation 2 as follows: 

Number of magnetron $=\frac{\text { Input electromagneticwave } \times \text { Cavity inside surface area }}{\text { Power of magnetron }}$

Cavity. A schematic diagram of electromagnetic waves in the cavity is illustrated in Figure 1. The cavity wall was made of two layers to reduce the leakage of electromagnetic waves. The inner layer was made of aluminium sheet, whereas the outer layer was made of stainless steel sheet. The cavity dimensions were $2410 \mathrm{~mm} \times 270 \mathrm{~mm} \times 210 \mathrm{~mm}(\mathrm{I} \times \mathrm{w} \times \mathrm{h})$.

Transmission line. A WR340 adapter was used as a microwave heating system operated at the frequency of $2.45 \mathrm{GHz}$ with a width/height ratio of 2:1.

Conveyor. The conveyor was designed to deliver seaweed samples in or out of the cavity. Copper was used as the primary material for the conveyor. An electric motor managed the speed of the conveyor with an adjustable frequency of the current.

\subsection{Performance Test}

The MD performance was tested using fresh $K$. alvarezii. Prior to each treatment, the seaweed was retrieved from the container, rinsed with tap water, and thawed at room temperature. The performance tests were performed by employing two variables, i.e., sample weights $(2,4,6 \mathrm{~kg})$ and power levels (700 and 1000 watts). The thickness of seaweed for each treatment was roughly $1.5-5 \mathrm{~cm}$, depending on the seaweed mass considered. The samples were fed into the cavity using the conveyor belt. After the samples were properly inserted, magnetrons' power level was set according to the desired power for 70 mins. Both exhaust fans were switched on during the process. The MD was switched off every 10 mins to weigh the samples until the process was completed. The MD's electric current and voltage were measured by a digital clamp meter during the running.

Various parameters, i.e., moisture ratio (MR), drying rates (DR), specific energy consumption (SEC)
(Horuz, Bozkurt, Karatas, \& Maskan, 2017) and energy efficiency (Zarein, Samadi, \& Ghobadian, 2015) were observed during the process.

The moisture ratio of the samples during drying was calculated using Equation 3.

$$
\mathrm{MR}=\frac{\mathrm{MC}_{\mathrm{t}}-\mathrm{MC}_{\mathrm{e}}}{\mathrm{MC}_{0}-\mathrm{MC}_{\mathrm{e}}}
$$

where $M R$ is moisture ratio, $M C_{t}, M C_{O}$ and $M C_{e}$ are the moisture content at any given time during drying, the initial moisture content, and the moisture equilibrium content in $\mathrm{g}$ water/g dry matter, respectively.

The drying rate $(D R)$ of seaweed in $\mathrm{g}$ water/mins was calculated from Equation 4.

$$
D R=\frac{d M t}{d t}=\frac{M_{0}-M_{t}}{\Delta t}
$$

where $M_{t}$ is the weight at any time, $M_{0}$ is the initial weight, and $\Delta t$ is time differences in mins.

The specific energy consumption of the examined MD was determined using Equation 5.

$$
\mathrm{SEC}=\frac{\mathrm{Q}}{\Delta \mathrm{m}} \mathrm{SEC}=\frac{\mathrm{Q}}{\Delta \mathrm{m}}
$$

where $S E C$ is the specific energy consumption ( $\mathrm{MJ} /$ $\mathrm{kg} . \mathrm{H}_{2} \mathrm{O}$ ).

$Q$ is the total energy absorbed microwave (Megajoule) and ${ }_{\Delta} \mathrm{m}$ is the amount of total moisture evaporated (kg) (Equation 6).

$$
\mathrm{Q}=\mathrm{V} \times \mathrm{I} \times \Delta \mathrm{t} \times \cos \mathrm{phi}
$$

where $I$ is the electric current $(A), V$ is the voltage (volt), $\Delta t$ is time on magnetron (mins) and cos phi value is 0.80 .

The energy efficiency $\eta$ of MD was calculated as the ratio of energy used for evaporating moisture and energy emitted from magnetrons. The calculation was performed using Equation 7.

$$
\eta=\frac{m_{w} \times A_{w}}{P \times t}
$$

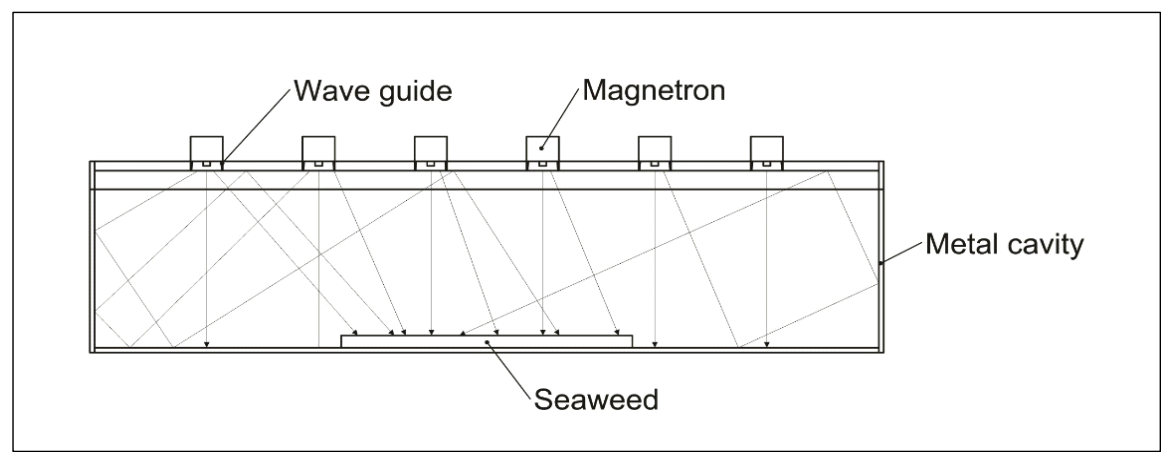

Figure 1. Schematic diagram of electromagnetic wave phenomena in the cavity 
where $\eta$ is the microwave drying efficiency (\%), $\mathrm{P}$ is microwave power $(\mathrm{kJ}), \mathrm{m}_{\mathrm{w}}$ is the mass of evaporated water $(\mathrm{kg})$, and $\lambda_{w}$ is the latent heat of evaporation of water $(2,257 \mathrm{~kJ} / \mathrm{kg})$.

\subsection{Analysis of Dried Seaweed Quality}

The determination of seaweed quality was performed using an FTIR. Prior to analysis, the dried seaweed was mixed with $\mathrm{KBr}$. The analysis was conducted by screening the samples between 4000 $400 \mathrm{~cm}^{-1}$. The spectra of the samples were compared to that of the sun-dried seaweed.

\subsection{Statistical Analysis}

All treatments were performed in triplicates. The data are presented as mean values +/- SD. One-way analysis of variance (ANOVA) and Tukey test in the Minitab program (Minitab, Version 17) were used to analyze each parameter's data. The mean values of parameter data were considered significantly different at a confidence level of $95 \%(p<0.05)$.

\section{Results and Discussion}

\subsection{Design}

The design and construction of the MD had been successfully assembled. Overall dimensions were 3510 (I) $\times 485$ (w) $\times 1205$ (h) mm while the cavity dimensions were $2410(\mathrm{l}) \times 270(\mathrm{w}) \times 210(\mathrm{~h}) \mathrm{mm}$. The cross-section drawing of the MD source is shown in Figure 2.

A $2.5 \mathrm{~kW}$ MD chamber was designed and constructed. The MD dryer consisted of two rooms, which functioned as the high voltage electrical components room and the drying compartment (cavity). The cavity consisted of a two-layer wall made of 2-mm-thick stainless steel 304 for the outer layer and 2-mm-thick aluminium for the inner layer. Aluminium is a good conductor material to reflect electromagnetic waves effectively. The cavity dimensions were $2410 \times 270 \times 210 \mathrm{~mm}(\mathrm{I} \times \mathrm{w} \times \mathrm{h})$ or approximately $0.14 \mathrm{~m}^{3}$ in volume.

\subsubsection{Air circulation system}

Eight units of the exhaust fan assisted the air circulation system. Four exhaust fan units were installed on the top of the electrical compartment to force ambient air out of the electrical components room and cool the magnetrons and the high voltage transformers. The other four units fans were placed on the rear of the cavity to draw the moisture out during the drying. The vapor flowed through a screen in the inner cavity wall and then released into the atmosphere. The four-mesh aluminium screen was designed to release the water vapor out and prevent microwave leakage.

\subsubsection{Drying system}

The electromagnetic wave input was $933 \mathrm{~mW} / \mathrm{cm}^{2}$ according to a commercial microwave oven. The inner cavity of the surface area was $6,500 \mathrm{~cm}^{2}$ and the power of magnetrons was $1 \times 10^{6} \mathrm{~mW}$ so that the obtained number of magnetrons was 6.1 units (round up to 6 units). The six magnetrons with a capacity of $1 \mathrm{~kW}$ operating at $2.45 \mathrm{GHz}$ were installed at the top side of the cavity wall. Multiple magnetron microwave systems have also been reported in previous studies (Harris, Brodie, Ozarska \& Taube, 2011). The distance between each magnetron was $400 \mathrm{~mm}$, and they were installed on top of the sample position to obtain a fair field distribution inside the cavity. The reflections from the inner part of the cavity wall provided further mixing. The magnetrons were equipped with an on-off switch to provide the required MD power to the drying chamber $(100,300,500,700$ and $1000 \mathrm{~W})$. The waveguide was generated from the WR340 adapter which was compatible with the magnetrons. Further, the sample was transferred in and out of the cavity using the conveyor belt.

\subsubsection{Control system}

The control system was equipped with a setup button to run the conveyor, an adjustment power for the magnetrons, an on-off switch for the fans and a digital countdown timer to set the drying period. The system control was installed in front of the MD for ease of operation (Figure 2).

\subsubsection{Operation}

When the magnetrons' power button was switched on, the magnetron immediately generated and emitted microwave energy (electromagnetic waves), transmitted to the cavity through a waveguide. The electromagnetic waves were radiated throughout the cavity surface. The emitting waves bounced off when they hit the cavity wall, and were absorbed when they collided with the seaweed. Seaweed is considered a dielectric material so that it can absorb the emitting wave. This absorption caused the evaporation of water in the seaweed. The combination of magnetron intensity and dehydration time can be adjusted, which is the microwave dryer's advantage (Hakim et al., 2019). 

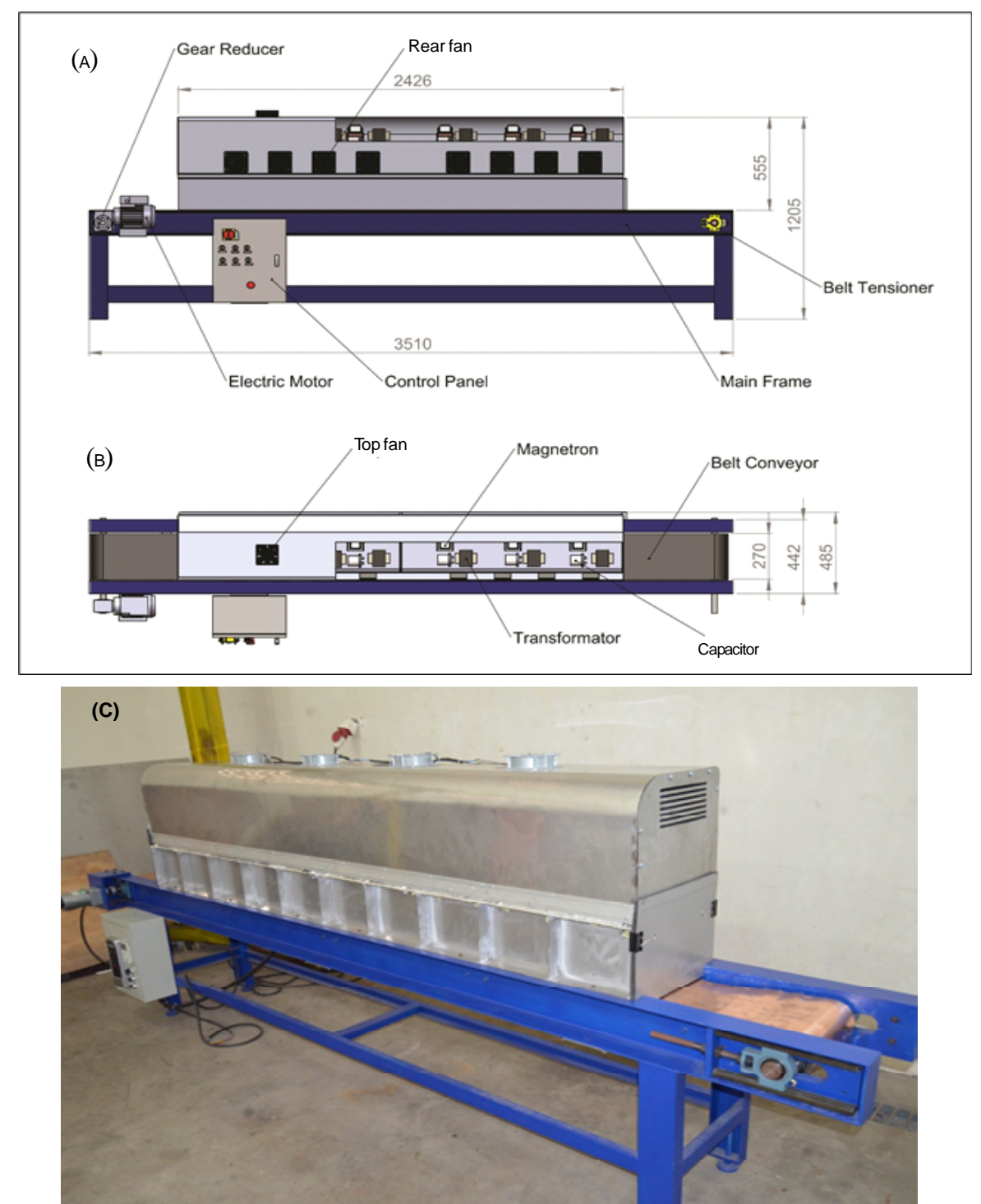

Figure 2. Microwave dryer design; front view (A), top view (B) and photograph (C)

\subsection{Performance of Microwave Dryer}

\subsubsection{Moisture ratio}

The MD performance to reduce the seaweed moisture content is described by a moisture ratio (MR) value (Figure 3). At the end of drying time, the MR for $\mathrm{P} 72$ was $0.28 \pm 0.21, \mathrm{P} 74$ was $0.40 \pm 0.05$, P76 was $0.68 \pm 0.05, \mathrm{P} 102$ was $0.12 \pm 0.09, \mathrm{P} 104$ was $0.24 \pm 0.01$ and $\mathrm{P} 106$ was $0.53+0.01$. Based on the obtained data, at the same loads of weight, differences in power level did not affect the MR value significantly. Meanwhile, the MR values of P76 and P106 were significantly different from other loads at the same power level.

The differences were caused by the fact that heavier load required more energy for the evaporation of moisture content; therefore, the final MR of P76 and P106 were higher than those of other treatments in the same drying period. Increasing the weight load also influenced the thickness of the seaweed that was placed in the cavity. The thickness of the material under microwave energy affects the electromagnetic wave's penetration (Fu, Chen \& Song, 2017; Hakim, Handoyo \& Prasetyo, 2020b; Jiang, Dang, Tan, Pan \& Wei, 2017). The optimum penetration allows increasing friction among water molecules in the seaweed. This friction provokes the evaporation of moisture from the seaweed rapidly, resulting in a decline of MR. This event occurred at both $2 \mathrm{~kg}$ and 4 $\mathrm{kg}$ loads.

Electromagnetic waves produced by the magnetrons comprise two ions, i.e., positive and negative; hence their motion is similar to a magnet. Materials that also have two ions will revolve when exposed to electromagnetic waves due to attractionrepulsion forces (Renshaw, 2016). The rotation was 
very high since the applied frequency was $2.45 \mathrm{GHz}$, which means that molecules rotated $2.45 \times 10^{9}$ times per second. High rotation generates friction between water molecules, producing heat (Hakim et al., 2020b; Rattanadecho \& Makul, 2016). It happens when wet or fresh material contains a bipolar molecule. This event causes a molecule to spin with high frequency and results in heating. Amiri-Chayjan, Kaveh and Khayati (2015) reported the considerable differences of vapor pressure between the core and the surface of the material escalates dehydration rates.

Because MR is a dimensionless parameter (Jafari et al., 2017; Torki-Harchegani et al., 2016; Zarein et al., 2015), it is difficult to compare to the other studies due to different conditions, e.g., the initial and the final target of moisture content, drying time and load number. Based on MR data, the designed MD was able to eliminate moisture content to less than 0.3 in the 70 -min process while loading 2 or $4 \mathrm{~kg}$ of seaweed.

\subsubsection{Drying rates}

Drying rates (DR) reveal the amount of removed moisture from the seaweed in unit time. The experimental data of drying rates measurement is showed in Figure 4. Based on this result, applying various loads did not significantly affect DR at either $\mathrm{P} 7$ or P10. The data revealed that drying fresh seaweed in the MD can be conducted at both P7 and P10. A different DR occurred only between P72 and P106. These results showed that the $D R$ value variation was likely due to a wide gap in sample load and strengthened by a higher power level. The heavier loads indicate more water content.

Higher water content leads to an increase in the dielectric loss factor, which accelerates the drying rates. Furthermore, at $\mathrm{P} 106$, the MD released electromagnetic wave radiation through magnetrons for a longer time than P72 due to the different periods of on-off of magnetrons. These differences affected friction among water molecules in the seaweed; hence, longer exposure time caused more prolonged friction. As a result, more water evaporated. Demiray et al. (2017) stated that microwave power had a substantial effect on the drying rate. The more considerable power of microwave leads to rapid mass transfer due to more heat generated in the sample, creating a large vapor pressure differential between the center and the material's surface. Ouertani et al. (2018) reported that increasing the power level of magnetrons enhances the material's internal gas pressure, forming a narrow space with radial orientation. Such an application also influences the structure of a material by gaining liquid and gas permeability.

Figure 4 shows the variations of $\mathrm{DR}(\mathrm{g} / \mathrm{min})$. The curves show that moisture removal of seaweed is fluctuated in the MD. In the beginning, the DR increased rapidly, then decreased overtime. In this study, the drying rate accelerated initially since the seaweed moisture content was very high and more energy was absorbed by the water, resulting in high moisture removal rates. As the drying process continued at two kilograms, the seaweed lost its moisture content and the dried surface caused electromagnetic waves penetration into the inner seaweed to decrease. This mechanism led to a decline in the absorption power and a decrease in the drying rate. Previous studies have revealed the same findings for microwave drying of different products, i.e., potato (Azimi-Nejadian \& Hoseini, 2019), peppermint leaves (Torki-Harchegani et al., 2016) and kiwi slice (Darvishi, Zaerin \& Farhudi, 2016). However, at four

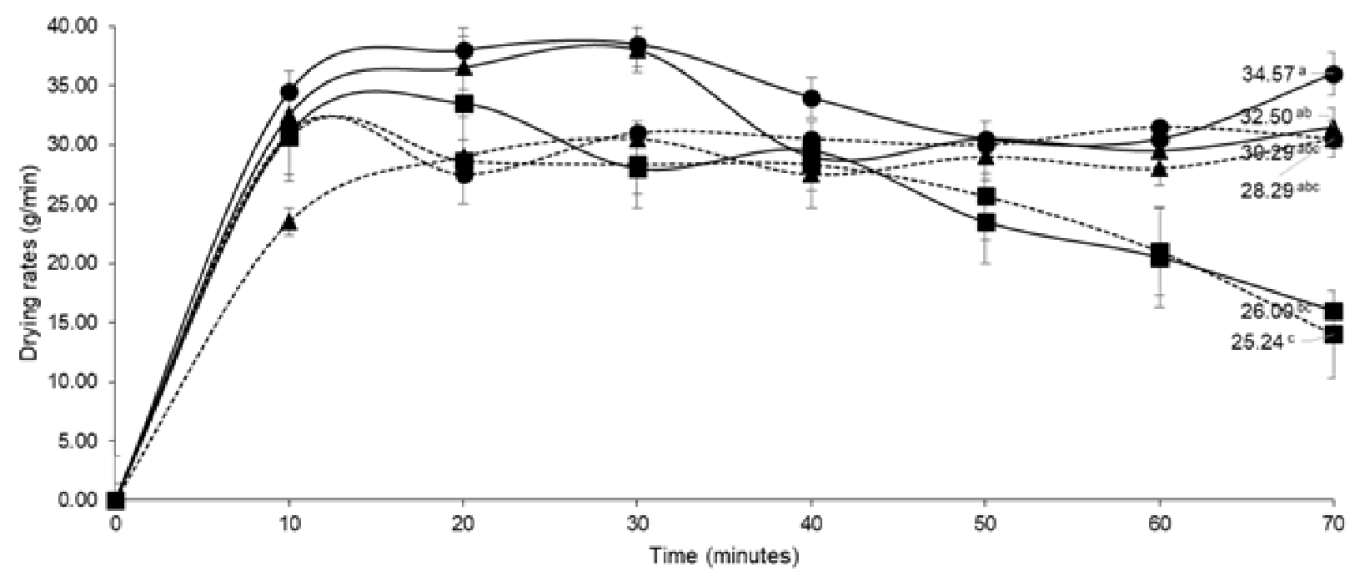

Figure 3. Effect of different level of power magnetron and load to moisture ratio. (-P72) power level 700 watt and load $2 \mathrm{~kg},(-\mathbf{-}-\mathrm{P} 74)$ power level 700 watt and load $4 \mathrm{~kg},(-\mathrm{e} 76)$ power level 700 watt and load $6 \mathrm{~kg},(-\mathbf{- P 1 0 2})$ power level 1000 watt and load $2 \mathrm{~kg},(-\mathbf{A}-104)$ power level 1000 watt and load $4 \mathrm{~kg}$, ( $\rightarrow$ - P106) power level 1000 watt and load $6 \mathrm{~kg}$ 


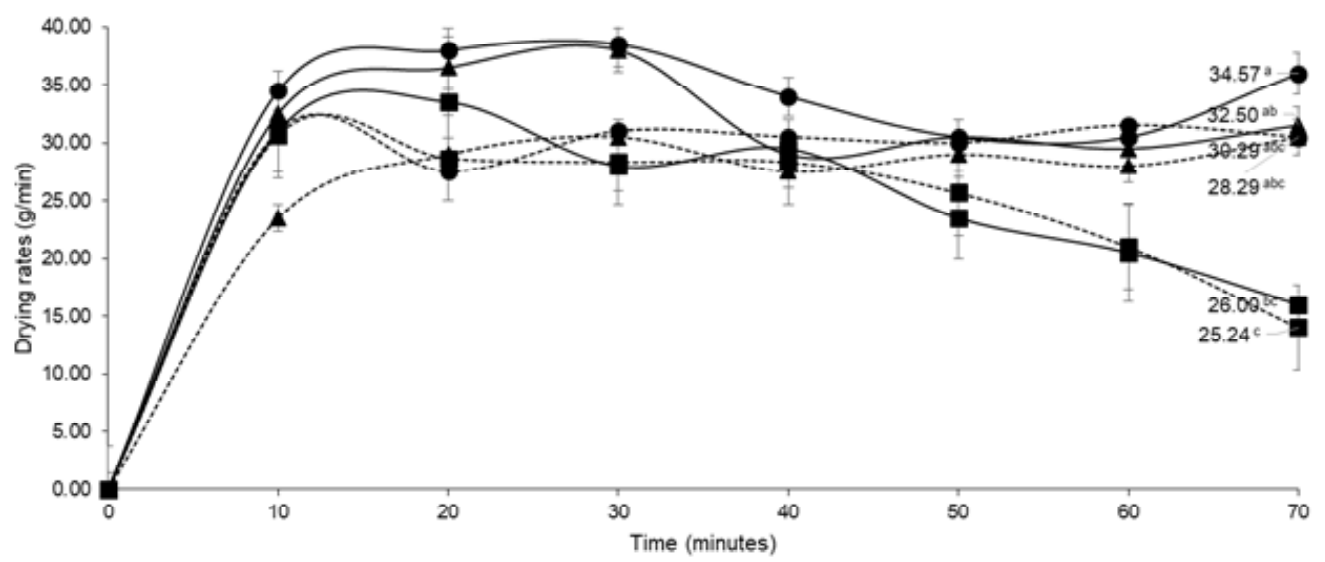

Figure 4. Drying rates of microwave dryer. Number with notation letter is average value of drying rates (-P72) power level 700 watt and load $2 \mathrm{~kg},-1$-P74) power level 700 watt and load $4 \mathrm{~kg}$, ( - P76) power level 700 watt and load $6 \mathrm{~kg},(-\mathrm{P} 102)$ power level 1000 watt and load $2 \mathrm{~kg}$, ( - -104) power level 1000 watt and load $4 \mathrm{~kg},(-\mathbf{P}$ 106) power level 1000 watt and load $6 \mathrm{~kg}$

kilograms loads, the DR increased again slightly in the final drying periods. It was probably caused by the moisture content remained high on this treatment. As stated by Fu et al. (2017), the sufficient moisture content in the material and the energy from the microwave lead to constant DR beyond the maximum DR point.

Furthermore, the DR observation revealed the quantity of evaporated moisture in the seaweed (Table 1). During the 70-minute drying process, the amount of evaporated water varied depending on the amount of seaweed. When the amount of evaporated moisture was converted to the initial weight percentage, the values would be smaller as loads became heavier (Table 1). It means, for instance, even though P106 had significantly higher DR than the other mass loads
(P102 and P72), it still had higher moisture content remaining at the end of the drying process. This result is higher than our previous study (Hakim et al., 2020b), which achieved the highest DR of $13.15 \mathrm{~g} / \mathrm{min}$ in drying seaweed using a microwave oven.

\subsubsection{Specific energy consumption (SEC)}

The absorption energy is affected by the exposure time to the magnetrons and the current. The detailed calculation and observation of the energy are illustrated in Table 2. The P10 power setting absorbs energy higher than the P7. It causes different exposure times. It is supported by the intermittent magnetrons observation in this study, which have on-off timing at the magnetrons of 53.1 and 6.9 seconds and 46 and 14 seconds for $\mathrm{P} 10$ and $\mathrm{P} 7$, respectively (Table 2 ).

Table 1. Comparison between average drying rates and evaporated moisture

\begin{tabular}{cccc}
\hline Treatments & Drying rates (g/min) & Evaporated moisture (g) & Evaporated moisture (\%) \\
\hline P72 & $25.24 \pm 5.84^{\mathrm{c}}$ & $1767 \pm 409^{\mathrm{c}}$ & $85.21 \pm 1.77^{\mathrm{a}}$ \\
P74 & $28.29 \pm 2.40^{\mathrm{abc}}$ & $1980 \pm 168^{\mathrm{abc}}$ & $49.32 \pm 0.35^{\mathrm{bc}}$ \\
P76 & $30.29 \pm 1.32^{\mathrm{abc}}$ & $2120 \pm 92^{\mathrm{abc}}$ & $35.22 \pm 0.71^{\mathrm{c}}$ \\
\hline P102 & $26.00 \pm 6.24^{\mathrm{bc}}$ & $1820 \pm 437^{\mathrm{bc}}$ & $88.56 \pm 0.71^{\mathrm{a}}$ \\
P104 & $32.50 \pm 3.48^{\mathrm{ab}}$ & $2275 \pm 243^{\mathrm{ab}}$ & $56.59 \pm 1.59^{\mathrm{b}}$ \\
P106 & $34.57 \pm 3.23^{\mathrm{a}}$ & $2420 \pm 226^{\mathrm{a}}$ & $40.23 \pm 0.24^{\mathrm{bc}}$ \\
\hline
\end{tabular}

Notes:

Different annotation letters indicate significant differences within the same column $(p<0.05)$

P72: power level 700 watt and load $2 \mathrm{~kg}$; P74 : power level 700 watt and load $4 \mathrm{~kg}$

P76: power level 700 watt and load $6 \mathrm{~kg}$; P102 : power level 1000 watt and load $2 \mathrm{~kg}$

P104: power level 1000 watt and load 4 kg; P106 : power level 1000 watt and load 6 kg 
Table 2. The average on/off times and energy consumption at different level powers

\begin{tabular}{|c|c|c|c|c|c|c|}
\hline \multirow{2}{*}{ Power setting } & \multicolumn{2}{|c|}{ Time (second) } & \multirow{2}{*}{ Current (A) } & \multirow{2}{*}{$\begin{array}{c}\text { Voltage } \\
\text { (V) }\end{array}$} & \multirow{2}{*}{$\begin{array}{l}\text { Power } \\
\text { (kWh) }\end{array}$} & \multirow{2}{*}{$\begin{array}{l}\text { Power } \\
\text { (kJ/h) }\end{array}$} \\
\hline & On & Off & & & & \\
\hline P7 & 46 & 14 & 14.8 & 220 & 2 & 7,203 \\
\hline P10 & 53.1 & 6.9 & 16.1 & 220 & 2.51 & 9,036 \\
\hline
\end{tabular}

Notes:

P7 : power level 700 watt; P10 : power level 1000 watt

The average values of the SEC for microwave drying of the seaweed are presented in Figure 5. The maximum SEC was $5.79 \pm 0.05 \mathrm{MJ} / \mathrm{kg} \mathrm{H}_{2} \mathrm{O}$ for $\mathrm{P} 102$, whereas the minimum was $3.96 \pm 0.08 \mathrm{MJ} / \mathrm{kg} \mathrm{H}_{2} \mathrm{O}$ for P76. According to the results above, this study's SEC range is comparable with microwave drying on a lab scale. The SEC decreased as the amount of sample load increased. The higher load mass at the same power level resulted in the energy reduction used due to the electromagnetic wave energy that was more absorbed or used by the seaweed for evaporation. Conversely, at lower load mass, the sample amount was insufficient to absorb all the energy exposed, thus reducing the evaporation process. Jafari et al. (2017) revealed that the load amount affects the SEC. The thicker the sample, the higher the moisture content; thus resulting to the decrease of SEC values. The drying process continued at a constant level of electromagnetic wave power when the moisture content dropped. This condition also caused the SEC value of the small load mass sample was higher than that of the big load. Ouertani et al. (2018) revealed that the decreasing energy consumption pattern occurred as the material mass increased. Meanwhile, the MD power and drying time remained steady. It means that the unit energy consumption was inversely related to the initial mass of material. This result was also comparable to the findings reported by Bermúdez, Beneroso, Rey-Raap, Arenillas and Menendez (2015) that the increase in the material mass from 5 to $100 \mathrm{~g}$ causes a decrease of SEC by $90-95 \%$. Other studies showed that potato slices in MD had an SEC of a 4.22-10.56 MJ/kg H $\mathrm{H}_{2} \mathrm{O}$ (Darvishi, 2012), peppermint leaves in MD 4.58-5.89 MJ/kg H $\mathrm{H}_{2} \mathrm{O}$ (Torki-Harchegani et al., 2016) and potato slices in microwave convective air drying an SEC of 8.95-10.78 MJ/kg H $\mathrm{O}_{2}$ (Soysal, 2009).

Figure 5 shows that the enhancement in the power level increased the SEC values significantly. Energy absorbed was $7,203 \mathrm{~kJ} / \mathrm{h}$ at $P 7$, whereas it was 9,035 $\mathrm{kJ} / \mathrm{h}$ at $\mathrm{P} 10$. The MD magnetrons produced electromagnetic waves in the same quantity in either P7 or P10; nevertheless, the exposure time varied. At longer exposure time, more energy was absorbed by seaweed. These findings were in agreement with the previous report (Azimi-Nejadian \& Hoseini, 2019). In their study, an increase in SEC is significantly influenced by the increasing power level of the microwave and the potato slice's thickness.

\subsubsection{Efficiency}

Figure 6 shows the fluctuating efficiency of the seaweed drying in MD. The lowest efficiency was $44.40 \pm 1.8 \%$ (P102), while the highest was $58.45 \pm$ 2.65\% (P76). At level power 7, P74 and P710 were significantly different, but P72 was not. At power level 10 , the efficiency increased as the load sample

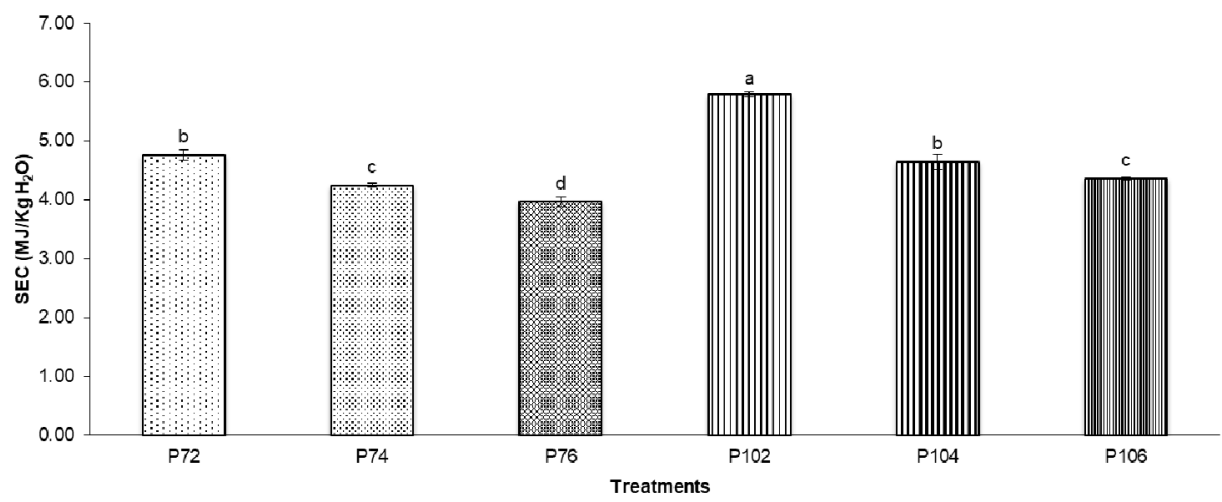

Figure 5. Average of SEC $\left(\mathrm{MJ} / \mathrm{kg} \mathrm{H}_{2} \mathrm{O}\right)$ at a different quantity of loads and powers of the magnetrons 


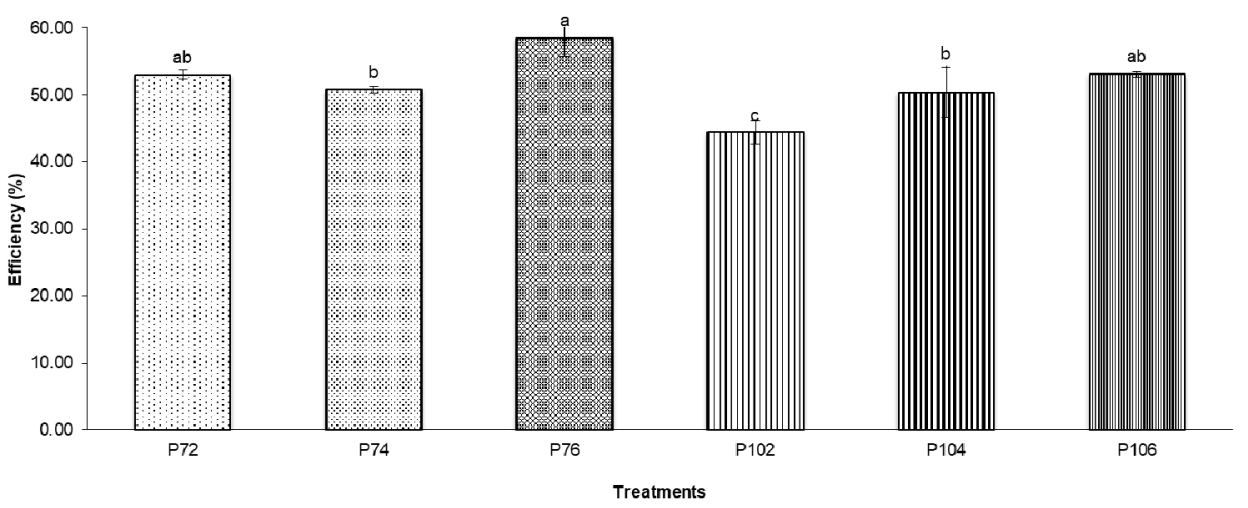

Figure 6. Average of efficiency energy (\%) of microwave drying

increased. The fluctuating efficiency might be influenced by the fact that the seaweed moisture content has not yet reached stability at the end of the drying process, particularly for 4 and $6 \mathrm{~kg}$ loads. As the moisture content in the material remained high, the evaporation process will continue to fluctuate. As a result, water removal also fluctuates. Similar fluctuation was also observed in MR and DR values.

Furthermore, in treatments $\mathrm{P} 104$ and $\mathrm{P} 106$, microwave energy penetrated more effectively than that of P102 that contains less mass. It causes only a small part of the waves to pass through the seaweed and collide with the cavity wall; therefore, energy loss was minimized. Bermúdez et al. (2015) obtained a similar result, and they stated that increasing the sample's quantity increased energy efficiency.

Differences in power level between P7 and P10 influenced only energy efficiency on 2 and $6 \mathrm{~kg}$ loads. At these loads, increasing the power level decreased efficiency. Jafari, Kalantari and Azadbakht (2018) reported that the strengthening of microwave power reduced energy consumption efficiency, drying and heating. In high sample loads, the effectiveness of wave penetration was optimum before the collision with the cavity wall. Microwaves were absorbed by the sample, resulting in an increase in drying efficiency.

Compared to the commercial microwave oven, the average energy efficiency of dried apples ranged from 17.42 to $54.34 \%$ (Zarein et al., 2015) and the highest efficiency of a continuous band for rice paddy drying was $59.06 \%$ with $18-\mathrm{mm}$ thick and 90 watts of power (Jafari et al., 2018). Another research reported that the optimum energy efficiency was $19.96 \%$ in a programmable air-circulating hybrid domestic microwave oven for drying 670-g sliced apples (Horuz, Bozkurt, Karata, \& Maskan, 2018). Based on the discussion above, the efficiency of MD can be increased by increasing the sample mass. A sample containing high moisture will more effectively absorb the electromagnetic wave.

\subsection{Seaweed Quality}

Based on MD's performances above, the P7 group achieved better performance than P10, as indicated by DR, SEC and efficiency parameters. Therefore, samples of P7 were chosen to be analysed for its quality compared to that of the sun drying process. In this study, the observed functional groups were sulfated esters, i.e., 3,6-anhydro-D-galactose and Dgalactose-4-sulfate. The presence of these groups indicates that dehydration in the MD does not degrade the carrageenan's quality. Further, the wavenumbers for carrageenan characteristics are sulfate ester at 1260-1218 cm 1 , 3,6-anhydro-D-galactose at 935-925 $\mathrm{cm}^{\prime \prime}$ and D-galactose-4-sulfate at $850-840 \mathrm{~cm}^{\prime \prime}$ (Sedayu, Cran \& Bigger, 2018; Wulandari, Pramesti \& Susanto, 2019).

Results of FTIR analysis showed that these functional groups were detected in dried seaweed and the spectra were identical in all treatments (Figure 7). The results were in agreement with those of Serowik et al. (2018) that concluded the solubility and rheological properties of carrageenan do not change after drying in microwave-assisted spouted bed drying. The drying process also did not affect the infrared spectrum of carrageenan significantly. The process may be due to the low dielectric loss factor of carrageenan related to the ability of a material to convert electromagnetic energy into heat (Feng, Yin, \& Tang, 2012). According to Turabi, Regier, Sumnu, Sahin and Rother (2010), the dielectric loss factor of carrageenan was only 0.23 .

The scaling up of the MD needs modification of the cavity and magnetrons that resulted in larger sample capacity and better performance in drying fresh seaweed than in the microwave oven (laboratory scale). As shown previously, fluctuations of parameter 


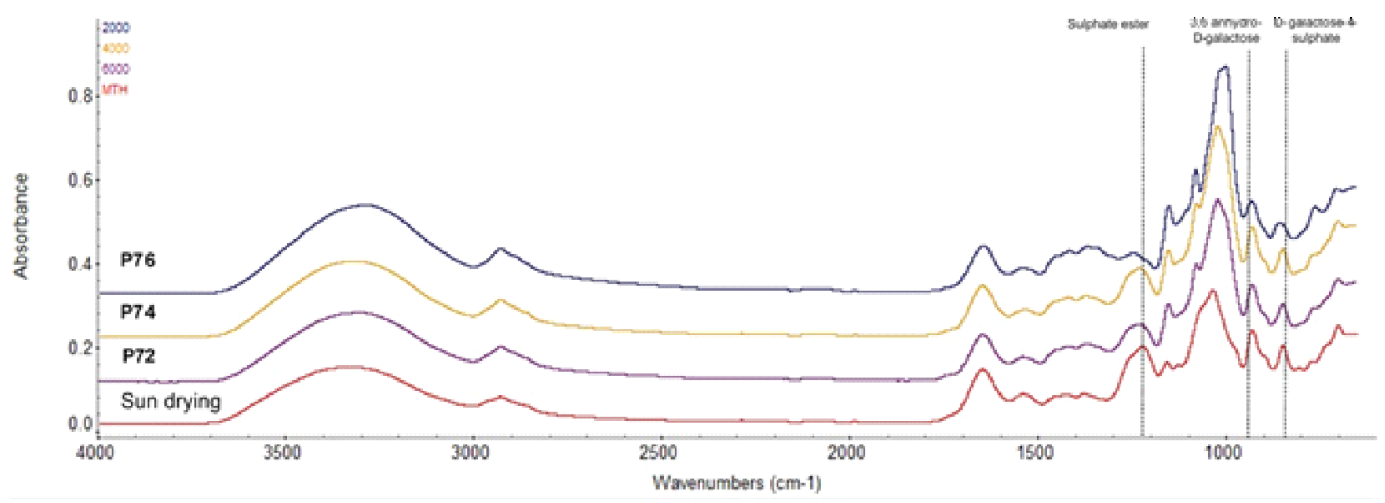

Figure 7. FTIR spectra of dried seaweed by various treatments; sun drying, P72, P74 and P76

values occurred, particularly in 4 and $6 \mathrm{~kg}$ loads. Therefore, monitoring the MD's performance is needed for more extended periods to obtain more stable evaporation of moisture.

\section{Conclusion}

A large scale MD has been designed and assembled witha cavity dimension of 2410 (I) $\times 270$ (w) $\times 210(\mathrm{~h}) \mathrm{mm}$. With the enlarged cavity and multiple magnetrons, the MD dehydrate dry fresh seaweed up to $6 \mathrm{~kg}$. The main components were cavity, air circulation system, drying system and control system. MD's optimum performance in drying fresh seaweed was $\mathrm{P} 7$ power level setting and six kilograms of load, achieved with energy efficiency $58.45 \%$, DR $30.29 \mathrm{~g} / \mathrm{min}$ and SEC $3.96 \mathrm{MJ} / \mathrm{kg}$. Changing both power levels and load mass quantity had not influence the MR and DR values but affected the SEC values and energy efficiency. Moreover, based on the FTIR spectrum, the functional groups of carrageenan in the dried seaweed were identical with the sun-dried seaweed. The result indicated that the seaweed quality was maintained during dehydration process. The application of microwave drying on fresh seaweed demonstrated time and energy savings, compared to the conventional drying methods.

\section{Acknowledgments}

This research was funded by the Indonesian Ministry of Marine Affairs and Fisheries, No. SP-DIPA032.12.2.403834. The authors acknowledge Farid Hidayat, who helped the MD's construction in the workshop of Indonesian Research Institute for Fisheries Postharvest Mechanization.

\section{References}

Adharini, R. I., Suyono, E. A., Suadi, Jayanti, A. D., \& Setyawan, A. R. (2019). A comparison of nutritional values of Kappaphycus alvarezii, Kappaphycus striatum, and Kappaphycus spinosum from the farming sites in Gorontalo Province, Sulawesi, Indonesia. Journal of Applied Phycology, 31(1), 725730. doi: 10.1007/s10811-018-1540-0

Amiri-Chayjan, R., Kaveh, M., \& Khayati, S. (2015). Modeling drying characteristics of hawthorn fruit under microwave-convective conditions. Journal of Food Processing and Preservation, 39(3), 239-253. doi: $10.1111 /$ jpp. 12226

Askari, G. R., Emam-Djomeh, Z., \& Mousavi, S. M. (2013). Heat and mass transfer in apple cubes in a microwave-assisted fluidized bed drier. Food and Bioproducts Processing, 91(3), 207-215. doi: 10.1016/j.fbp.2012.09.007

Atuonwu, J. C., \& Tassou, S. A. (2018). Quality assurance in microwave food processing and the enabling potentials of solid-state power generators: A review. Journal of Food Engineering, 234, 1-15. doi: 10.1016/ j.jfoodeng.2018.04.009

Azimi-Nejadian, H., \& Hoseini, S. S. (2019). Study the effect of microwave power and slices thickness on drying characteristics of potato. Heat and Mass Transfer/Waerme- Und Stoffuebertragung, 55(10), 2921-2930. doi: 10.1007/s00231-019-02633-x

Bermúdez, J. M., Beneroso, D., Rey-Raap, N., Arenillas, A., \& Menéndez, J. A. (2015). Energy consumption estimation in the scaling-up of microwave heating processes. Chemical Engineering and Processing: Process Intensification, 95, 1-8. doi: 10.1016/ j.cep.2015.05.001

Darvishi, H. (2012). Energy consumption and mathematical modeling of microwave drying of potato slices. Agricultural Engineering International: CIGR Journal, 14(1), 94-102.

Darvishi, H., Zarein, M., \& Farhudi, Z. (2016). Energetic and exergetic performance analysis and modeling of drying kinetics of kiwi slices. Journal of Food Science and Technology, 53(5), 2317-2333. doi: 10.1007/ s13197-016-2199-7

Demiray, E., Seker, A., \& Tulek, Y. (2017). Drying kinetics of onion (Allium cepa L.) slices with convective and microwave drying. Heat and Mass Transfer/WaermeUnd Stoffuebertragung, 53(5), 1817-1827. doi: $10.1007 / \mathrm{s} 00231-016-1943-x$ 
Djaeni, M., Sasongko, S. B., \& van Boxtel, A. J. B. (2013). Enhancement of energy efficiency and food product quality using adsorption dryer with zeolite. International Journal of Renewable Energy Development, 2(2), 81-86. doi: 10.14710/ijred.2.2.8186

Djaeni, Mohamad, \& Sari, D. A. (2015). Low temperature seaweed drying using dehumidified air. Procedia Environmental Sciences, 23, 2-10. doi: 10.1016/ j.proenv.2015.01.002

El-Mesery, H. S., \& Mwithiga, G. (2015). Performance of a convective, infrared and combined infraredconvective heated conveyor-belt dryer. Journal of Food Science and Technology, 52(5), 2721-2730. doi: 10.1007/s13197-014-1347-1

Feng, H., \& Tang, J. (1998). Microwave finish drying of diced apples in a spouted bed. Journal of Food Science, 63(4), 679-683. doi: 10.1111/j.13652621.1998.tb15811.x

Feng, Hao, Yin, Y., \& Tang, J. (2012). Microwave drying of food and agricultural materials: Basics and heat and mass transfer modeling. Food Engineering Reviews, 4(2), 89-106. doi: 10.1007/s12393-012-9048-x

Fu, B. A., Chen, M. Q., \& Song, J. J. (2017). Investigation on the microwave drying kinetics and pumping phenomenon of lignite spheres. Applied Thermal Engineering, 124, 371-380. doi: 10.1016/j.appl thermaleng.2017.06.034

Fudholi, A., Sopian, K., Othman, M. Y., \& Ruslan, M. H. (2014). Energy and exergy analyses of solar drying system of red seaweed. Energy and Buildings, 68(PARTA), 121-129. doi: 10.1016/j.enbuild. 2013.07.072

GAE-Gerling Applied Engineering Inc. (2009). Application Bulletin : Cut-off Tube Design

Harris, G.A., Brodie, G. I. , Ozarska, B., \& Taube, A.. (2011). Design of a microwave chamber for the purpose of drying of wood components for furniture. Transactions of the ASABE, 54(1), 363-368. doi: 10.13031/ 2013.36246

Hakim, A.R., Handoyo, W.T., Prasetyo, A. (2020a). A simulation study of parameters influencing microwave heating of seaweed (Eucheuma cottonii). Journal of Physics: Conference Series, 1444(1). doi: 10.1088/1742-6596/1444/1/011001

Hakim, A.R., Handoyo, W.T., Prasetyo, A. (2020b). Performa dan analisis konsumsi energi pengeringan rumput laut menggunakan energi gelombang mikro. Jurnal Pascapanen dan Bioteknologi Kelautan dan Perikanan, 15(1), 85-97. doi: 10.15578/jpbkp. v15i1.639

Hakim, A.R., Handoyo, W.T., Prasetya, A.W. (2019). Rancang Bangun Alat Pengering Rumput Laut Menggunakan Gelombang Mikro. Laporan Teknis Kegiatan Riset. Loka Riset Mekanisasi pengolahan Hasil Perikanan.

Horuz, E., Bozkurt, H., Karatao, H., \& Maskan, M. (2017). Drying kinetics of apricot halves in a microwave-hot air hybrid oven. Heat and Mass Transfer/Waerme- Und Stoffuebertragung, 53(6), 2117-2127. doi: 10.1007/ s00231-017-1973-z
Horuz, E., Bozkurt, H., Karataํ, H., \& Maskan, M. (2018). Simultaneous application of microwave energy and hot air to whole drying process of apple slices: drying kinetics, modeling, temperature profile and energy aspect. Heat and Mass Transfer/Waerme- Und Stoffuebertragung, 54(2), 425-436. doi: 10.1007/ s00231-017-2152-y

Jafari, H., Kalantari, D., \& Azadbakht, M. (2017). Semiindustrial continuous band microwave dryer for energy and exergy analyses, mathematical modeling of paddy drying and it's qualitative study. Energy, 138, 1016-1029. doi: 10.1016/j.energy.2017.07.111

Jafari, H., Kalantari, D., \& Azadbakht, M. (2018). Energy consumption and qualitative evaluation of a continuous band microwave dryer for rice paddy drying. Energy, 142, 647-654. doi: 10.1016/ j.energy.2017.10.065

Jiang, J., Dang, L., Tan, H., Pan, B., \& Wei, H. (2017). Thin layer drying kinetics of pre-gelatinized starch under microwave. Journal of the Taiwan Institute of Chemical Engineers, 72, 10-18. doi: 10.1016/ j.jtice.2017.01.005

Jumaidin, R., Sapuan, S. M., Jawaid, M., Ishak, M. R., \& Sahari, J. (2017). Characteristics of Eucheuma cottonii waste from East Malaysia: physical, thermal and chemical composition. European Journal of Phycology, 52(2), 200-207. doi: 10.1080/096702 62.2016.1248498

Monteiro, R. L., Carciofi, B. A. M., Marsaioli, A., \& Laurindo, J. B. (2015). How to make a microwave vacuum dryer with turntable. Journal of Food Engineering (166, 276-284). doi: 10.1016/j.jfoodeng. 2015.06.029

Naim, M., Burhanuddin, B., Lapondu, D., \& Roslan, R. (2018). Rancang bangun prototipe oven pengering rumput laut untuk UKM di wilayah Kabupaten Luwu Timur. Dinamika: Jurnal Ilmiah Teknik Mesin, 10(1), 47-54. doi: 10.33772/djitm.v10i1.4845

Ouertani, S., Koubaa, A., Azzouz, S., Bahar, R., Hassini, L., \& Belghith, A. (2018). Microwave drying kinetics of jack pine wood: determination of phytosanitary efficacy, energy consumption, and mechanical properties. European Journal of Wood and Wood Products, 76(4), 1101-1111. doi: 10.1007/s00107018-1316-x

Rattanadecho, P., \& Makul, N. (2016). Microwave-assisted drying: A review of the state-of-the-art. Drying Technology, 34(1), 1-38. doi: 10.1080/07373 937.2014.957764

Renshaw, R. (2016). New insights into RF and microwave drying of foods. PhD thesis, University of Nottingham.

Sedayu, B. B., Cran, M. J., \& Bigger, S. W. (2018). Characterization of semi-refined carrageenan-based film for primary food packaging purposes. Journal of Polymers and the Environment, 26(9), 3754-3761. doi: 10.1007/s10924-018-1255-y

Serowik, M., Figiel, A., Nejman, M., Pudlo, A., Chorazyk, D., Kopec, W., ... \& Rychlicka, J. (2018). Drying characteristics and properties of microwave-assisted spouted bed dried semi-refined carrageenan. Journal of Food Engineering, 221, 20-28. doi: 10.1016/ j.jfoodeng. 2017.09.023 
Soysal, Y. (2009). Intermittent and continuous microwaveconvective air drying of potato (Lady rosetta): Drying kinetics, energy consumption and product quality. Tarým Makinalarý Bilimi Dergisi, 5(2), 139-148.

Surata, I.W., Nindhia, T.G.T., \& Atmika, I.K.A. (2012). Quality improvement of dried seaweed by using cabinet dryer. Proceedings of th $2^{\text {nd }}$ International Conference on Sustainable Technology Development, M-129-M135, Udayana University Press, Denpasar

Torki-Harchegani, M., Ghanbarian, D., Ghasemi Pirbalouti, A., \& Sadeghi, M. (2016). Dehydration behaviour, mathematical modelling, energy efficiency and essential oil yield of peppermint leaves undergoing microwave and hot air treatments. Renewable and Sustainable Energy Reviews, 58, 407-418. doi: 10.1016/j.rser.2015.12.078

Turabi, E., Regier, M., Sumnu, G., Sahin, S., \& Rother, M. (2010). Dielectric and thermal properties of rice cake formulations containing different gums types. International Journal of Food Properties, 13(6), 11991206. doi: 10.1080/10942910903013365

Wang, J., \& Xi, Y. S. (2005). Drying characteristics and drying quality of carrot using a two-stage microwave process. Journal of Food Engineering, 68(4), 505511. doi: 10.1016/j.jfoodeng.2004.06.027

Wulandari, N. S., Pramesti, R., \& Susanto, A. B. (2019). Analisis parameter fisika dan kimia karaginan Kappaphycus alvarezii Doty 1985 (Florideophyceae: Solieriaceae) dengan variasi ekstraksi dari perairan Bluto. Journal of Marine Research, 8(4), 409-415.

Zarein, M., Samadi, S. H., \& Ghobadian, B. (2015). Investigation of microwave dryer effect on energy efficiency during drying of apple slices. Journal of the Saudi Society of Agricultural Sciences, 14(1), 41-47. doi: 10.1016/j.jssas.2013.06.002 